\title{
Policy Formulation During Pandemic COVID-19: A New Evidence of Multiple Streams Theory from Yogyakarta, Indonesia
}

\author{
Agus Heruanto Hadna \\ Department of Management and Public Policy, Faculty of Social and Political Sciences, \\ Universitas Gadjah Mada (UGM) - Indonesia; \\ Graduate School of Leadership and Policy Innovation, Universitas Gadjah Mada (UGM) - \\ Indonesia
}

Received: Jun. 13, $2021 \quad$ Accepted: Jul. 19, 2021 Online published: Aug. 20, 2021

doi:10.5296/jpag.v11i3.18741ＵRL: https://doi.org/10.5296/jpag.v11i3.18741

\begin{abstract}
This study aims to answer how the policy formulation process resolves the pandemic's impact in DIY Province, Indonesia, in 2020. DIY is chosen as the case in this study because the governor is also a king in this region. It was also considered the best province in handling the pandemic Covid-19 in 2020. This study used multiple streams proposed by John W. Kingdon to elaborate on the policy formulation process. This research method is qualitative, conducted using an online questionnaire, in-depth interview, documentary from March to October 2020. It found that policy, problems, and political streams overlapped in a policy window, i.e., pandemic crisis, as a common concern that must be addressed immediately. The new finding is that the government administration system that combines monarchy and decentralization models has encouraged crises to be resolved more quickly through an integrated multiple streams formulation. The other new finding is the governor, as a policymaker, can take advantage of the pandemic as a policy window to act as the sole policy entrepreneur.
\end{abstract}

Keywords: policy formulation, multiple streams, policy entrepreneur, policy window, pandemic covid-19

\section{Introduction}

The policy formulation process is one of the most crucial stages in the policy process. The success of this stage will determine the following steps of policy. In policy studies' early development, such a mindset is commonly associated with a typical system theory model. For instance, Easton (1965) explains how the input stage in demand and support initiated the political process. Both subsequently undergo a process that occurs within the political system. 
This process ends by producing decisions and actions as the output of the system. The performance of this output is as feedback for the input stage (Easton, 1965). However, in practice, it frequently differs in implementing policy practices. Studies conducted by Colebatch (2006), Brzezinski et al. (2013), and Basheka \& Byamugisha (2015) persuasively demonstrate how the actual implementation of a designed policy can substantially differ from previous theories. Basheka \& Byamugisha (2015) conducted a study that influences Africa's policymaking process compared to the prevailing public policy theory. Basheka \& Byamugisha (2015) also illustrated Africa's local governance culture, especially a Ndebele polity apparatus. The governance showed an elaboration of mechanisms with checks and balances that significantly regulated the king's power. The hierarchy of power facilitated communication between the leaders and the ordinary people, the lesser chiefs, and the senior leaders, up to the king.

Some policy formulation theories previously come from the rational policy paradigm. However, this paradigm's fault cannot explain the relationship between the problem and the policy solution (Sabatier, 2007; Zohlnhöfer, 2016). Policymaking is not a rational response to clearly defined social or economic issues (J. W. Kingdon \& Brodkin, 2014; Zohlnhöfer, 2016). Simon (1955) criticized the rational mode weakness by the theory of bounded rationality. Studies from Blomkamp et al. (2017) and Pellini et al. (2018) suggest that the policy cycle steps - from agenda-setting to policy evaluation - do not align with Indonesia's actual practice of policymaking. Blomkamp et al. (2017) emphasized some stages in the policy cycle, such as consultation and evaluation by the state, were not prominent in practice. Meanwhile, the policy process did not conduct policy analysis, decision-making, and coordination sequentially (Blomkamp et al., 2017; Pellini et al., 2018).

Several weaknesses in the previous policy formulation process resulted in other approaches. One of the contrasting perspectives for analyzing policy formulation is the garbage can model proposed by Cohen et al. (1972). The model has organized anarchy dwelling on problematic preferences, unclear technology, and flowing participation (J. W. Kingdon \& Brodkin, 2014; Zahariadis, 2008). The organization is not regulated based on predetermined standards. The decisions taken are ultimately inconsistent and structured according to the vision and mission of the organization. As a result, more decisions are under conditions of ambiguity (Zahariadis, 2008). All these factors potentially cause decision-making that is similar to the "garbage can" model. In this model, Cohen et al. (1972) argue that "a decision is a result or interpretation of several relatively independent streams within an organization: the choice flow, the problem flow, the solution flow rate, the energy flow from the participants."

The garbage can paradigm has inspired one of the well-known theoretical models of policy processes, i.e., a Multiple Streams Approach developed by J. W. Kingdon \& Brodkin (2014) in his book, "Agendas, Alternatives, and Public Policies." In the book, Kingdon obtained his study material in health and transportation policy in the U.S., which underlines that policymaking is not rational in solving policy problems (Zohlnhöfer, 2016). According to Kingdon, time significantly constrained policymakers, thus solving problems generally uses the heuristic method (Sabatier, 2007; Zahariadis, 2008; Eising, 2013). This study tried to use the Multiple Stream (M.S.) model proposed by J. W. Kingdon \& Brodkin (2014) to analyze 
how policymakers in Yogyakarta Special Province (DIY) in Indonesia handle the Covid-19 pandemic, particularly in health, economics, transportation, and social safety nets.

These specific cases depend on the unique locus and governance. A study conducted by Kurniadi (2009) in DIY showed this government history. It had been built and led by a king (Sultan) who also serves as a governor. Indonesian Constitution Law Number 13 (2012) stipulates concerning DIY's privileges: leadership (governor), bureaucracy, culture, land, and spatial.

Sabatier (2007) criticized the M.S. approach that the multiple-streams framework has no explicit hypotheses. It is also fluid in its structure and operationalization that falsification is difficult (Zohlnhöfer, 2016). However, this approach is still useful for analyzing cases in DIY. The reason is the similarity of several policy formulation variables during this pandemic with the multiple streams model. The other reason is Blomkamp et al. (2017) suggestion that to understand better the policy networks and practices in Indonesia could further uncover who is involved in the process, what evidence they use, and how they can shape debates on particular issues.

This theory will analyze how the streams of problems, policy, and politics interact with each other, what the policy window appears, and who the policy entrepreneur handles the Covid 19 pandemic. Mintrom \& Norman (2009) suggested that there is also a need for more study of the interactions between policy entrepreneurs and their specific policy contexts. Context greatly influences policy choices because the policy problems to be resolved are generally very multidimensional and ill-structured. This condition forces decision-makers to move from a way of thinking to another when dealing with a public issue (Mintrom \& Norman, 2009; Zahariadis, 2008). The study argues that combining the monarchy system and the decentralized unitary state system in an administration system will have its policymaking model as a particular context in this research area. According to such understanding, this study will subsequently examine how the provincial government's policy formulation practices during pandemic covid 19.

Based on the number of COVID-19 cases in DIY as of October 2020, 3,835 people were infected, recovered 3,147 people, and 93 people died. The number of layoffs affected 101,805 people, or 4.57 percent of the total workforce of 2,2 million people (Tribunjogja.com, 2020). At the national level, the economic growth in this province has decreased by 6 percent to be -2.69 percent (Tribunjogja.com, 2020). The amount of central government spending in this province in 2020 has been adjusted and dropped to IDR 10,04 trillion. The realization of budget expenditures was only 63.16 percent until September 2020 (jogjaprov.go.id, n.d.).

\section{Theoretical Framework}

During the 2020 Pandemic in DIY, the policy formulation crisis shows an irregular pattern of problems and policies streams. Moreover, many variables determine the policy formulation process. Hence, this research's theoretical framework used W. J. Kingdon \& Stano (1984) and J. W. Kingdon \& Brodkin (2014) through M.S. theory. Kingdon explained that M.S. consists of problem identification (Problem stream), solution production (Policy stream), and choice 
(Politics Stream).

\subsection{The Problem Streams}

The problem stream is a public perceived problem shared by the public and policymakers because it has disrupted life together (Zahariadis, 2008; Eising, 2013). It is the perception of a public affair that requires government action that may overcome it. Therefore, the public problem is a policy problem. This policy problem has the characteristics of interdependency, subjective, artificial, dynamic (Dunn, 2018). This feature forces public problems to be comprehensive (holistic), which is the subsystem as an inseparable part of the more extensive system that binds it. (Mitroff \& Blankenship, 1973).

J. W. Kingdon \& Brodkin (2014) and Eising (2013) mention several components in problem streams: indicators to measure change, focus on the momentum of an event, feedback, budget constraints, and how the problem is defined. Policymakers consider the existence of change indicators because decision-making obtains information from specific political pressures and comes from evidence-based policy indicators. Policymakers need this indicator to measure the magnitude of the change to be more concerned with the problem (J. W. Kingdon \& Brodkin, 2014). However, indicators of change are not always available in the policy information. Momentum factors of events such as crises, disasters, or symbols of change that are currently emerging, including the experience of individual decision-makers, encourage policy issues to get the public and the government's attention (J. W. Kingdon \& Brodkin, 2014). Ambiguity situations like this make it difficult to unify the understanding of thinking (Feldman, 1989; Zahariadis, 2008; J. W. Kingdon \& Brodkin, 2014). The similarity in defining policy issues will make it easier for the government to complete the policy agenda (J. W. Kingdon \& Brodkin, 2014). Theoretical discussion of M.S. above by Cairney \& Jones (2016) concluded that "Problem stream - attention lurches to a policy problem, Policy stream - a solution to the problem is available, and Politics stream - policymakers have the motive and opportunity to turn a solution into policy."

This study examines problem streams based on how the community, executive, and legislature in DIY define a crisis as a common problem. Another question is how the executive responds to the crisis according to the legislative perception of the health, economic, transportation, and social assistance sectors. What exactly is the executive doing when the crisis begins. This study also examines the availability of the local budget and the executive solidity to decide the pandemic budget. In differences in perceptions between these agencies, the governor's role is mediating frictions between agencies to make mutual agreements between actors.

\subsection{Policy Streams}

A policy stream is a solution offered by the community, experts, and other stakeholders in responding to problems (Eising, 2013). The idea of a policy solution must first go through the debate stage with the support of science and technology (evidence-based policy). This idea must also get public support because of the similarity of both the problem and the solution. In this case, J. W. Kingdon \& Brodkin (2014) relies on the role of policy communities as groups 
of experts and other stakeholders who will discuss options for available policy solutions.

The concept of policy communities encourages the emergence of Policy Entrepreneurs, namely, those who carry out an advocacy function when trying to make policy changes. (Mintrom \& Norman, 2009; Eising, 2013). W. J. Kingdon \& Stano (1984) and (J. W. Kingdon \& Brodkin (2014) noted that policy entrepreneurs "could be in or out of government, in elected or appointed positions, in interest groups or research organizations."The motivations of policy entrepreneurs include helping the government solve public problems, forming policy ideas that are following the values they believe in, and the desire always to be close to the decision-making ring (J. W. Kingdon \& Brodkin, 2014). Policy entrepreneurs have a role in softening up problematic policy ideas because they do not meet technical and scientific criteria, the level of public acceptance, budget availability, and meet the interests of decision-makers (J. W. Kingdon \& Brodkin, 2014; Mintrom, 2011; Mintrom \& Norman, 2009). The role of policy entrepreneurs can combine three streams that produce policy changes (Colebatch, 2006; Sabatier, 2007; Zahariadis, 2008; J. W. Kingdon \& Brodkin, 2014).

These policy streams examine the basis of the DIY government in making decisions. When valid and reliable data is not available, how does the local government make decisions and the community's response? The unavailability of data encourages each agency to interpret its pandemic handling program. Through these policy streams, it is increasingly visible how the role of regional heads as policy entrepreneurs in solving problems is. Mintrom \& Norman (2009) argue that these policy entrepreneurs have several functions: the ability to read issues, define problems, and build networking. This study examines how policy entrepreneurs role is in handling the COVID-19 pandemic in DIY.

\subsection{Political Streams}

The last stream is a political stream. Political streams occur and generally flow freely between problems and policy streams (J. W. Kingdon \& Brodkin, 2014). Political streams consist of many factors, such as changes in national conditions, changes in officials and members of parliament, and campaigns that are of pressure to be carried out by interest groups, including political parties (J. Kingdon \& Stano, 1984; Eising, 2013; J. W. Kingdon \& Brodkin, 2014; Novotny et al., 2015). In other words, J. W. Kingdon \& Brodkin (2014) states that political streams consist of the public mood, pressure group campaigns, election results, partisan or ideological distributions in parliament, and changes of government (Zahariadis, 2008; Sabatier, 2007).

The study analyzes the national mood and its implications in the center and local government relationship in DIY in political streams, including central support to ensure the security of regional officials in making policies to handle the COVID-19 pandemic. In addition, the analysis pays attention to social and political conditions in DIY, especially the level of hidden conflicts that influence the policy agenda. The term of politics includes explaining how the DPRD's political position in the government system in DIY and the frictions of interest that occur in the executive. According to Kingdon, the elected and appointed officials are important actors in the agenda-setting process, and they are generally the most influential 
actors among the agenda setters (J. W. Kingdon \& Brodkin, 2014; Novotny et al., 2015). The combination of political and administrative abilities and supported by the cultural position allows the governor to have a role as a policy entrepreneur.

The implication of these streams is the emergence of the policy window. It refers to where policy entrepreneurs fight multiple streams to push their pet solutions or make attention to their particular problems. J. W. Kingdon \& Brodkin (2014) analogizes the convergence of the three streams to a policy referred to as "primeval soup policy," which takes time to do "softening" so that many actors can accept the issue in a policy subsystem (Cairney \& Jones, 2016). The policy window is generally open for a limited time. Political streams such as changing the government regime, changing the political constellation in parliament, or shifting a national mood, can open the policy window.

Meanwhile, from the aspect of problem streams, the window is open due to public issues that are trending and become a common problem. Crises, disasters, and changes in positions in the bureaucracy are also factors that determine whether or not the policy window is open. Finally, the window will be closed when there are no mutually agreed policy alternatives (J. W. Kingdon \& Brodkin, 2014).

The primeval soup policy requires policy entrepreneurs' intervention to fight for alternative approaches that all parties accept. Kingdon's M.S. theory explains that a person or group must be a policy entrepreneur who tries to harmonize problems, solutions, and politics behind a policy output. The entrepreneurial policy consists of three categories, i.e., individual policy entrepreneurs, collective policy entrepreneurs, and donor organizations (Meijerink \& Huitema, 2010). Overall, J. W. Kingdon \& Brodkin (2014) states that policy entrepreneurs are vital actors in advocating alternative solutions when the policy windows are open into a legal policy. There are four policy entrepreneurship elements: displaying social acuity, defining problems, building teams, and leading by example (Mintrom \& Norman, 2009).

If the Kingdon model tries to put the three streams in balance, will the formulation process produce the final decision? There is a policy entrepreneur who can unite various interests. In the context of handling Covid-19, it confirms that a governor acts as a policy entrepreneur that accommodates different opposing streams. Kingdon \& Stano (1984) argued that within the policymaking process, policy entrepreneurs take advantage of "windows of opportunity" to promote policy change (Mintrom \& Norman, 2009). This study tries to answer how pandemics as a public problem can shift into a policy window. It could also be a novelty that can be an input for knowledge development on how crises help break the policy deadlocks due to different institutional missions and competition among high-level public officials. The role of policy entrepreneurs in opening policy windows to handle a pandemic's impact is interesting to examine.

It is in contrast to a conclusion from (Pellini et al., 2018). They concluded that without acceptance by civil servants within the bureaucracy, leadership (even from the very top) alone could not change behaviors and attitudes towards the use of evidence in policymaking. On the other hand, this study found the significant role of the DIY top leaders (governors) in determining the data, the policy process, and the results. The position of civil servants in the 
policy formulation process is to translate the governor's vision.

The researcher analyzed the DIY policy formulation to determine the similarities and differences using the Kingdon model's formulation process. The study highlighted a conclusion formed by the researcher about the overall meaning obtained from the DIY policies' formulation process.

\section{Research Method}

The method of this study is qualitative research. This study focused on the case of policy formulation in health, economics, transportation, and social safety nets in DIY during the pandemic Covid-19 in 2020. Through those policies, the researcher attempted to identify the policy formulation process.

This study selected policymaking in DIY, given its status as the oldest province in Indonesia. It also has a unique administration model that combines a monarchical model with a decentralized government. Furthermore, the central government has claimed that DIY was a successful province in preventing the pandemic Covid-19 in 2020.

This research was initially through a desk study process, which began in March 2020 and ended in October 2020. The data collecting is by online questionnaires, interviews by phone, and documentaries. The primary data is questionnaires from higher-ranking public officials of the local government at provincial and district levels (PEMDA) and all local legislative members at provincial and district levels (DPRD). In addition, the data collecting is in-depth interviews with eight critical informants from higher-ranking public officials directly involved in the technical process of policy formulation from the PEMDA (4 informants) and DPRD (4 informants). In the initial stage, prepared a map analysis of stakeholders holding a role in policymaking. The researcher also played as a researcher in DIY administration, often following the provincial and districts policy process since 2016. The research also found some other actors according to the recommendations of key informants (snowball technique).

The questionnaires were shared with all policymakers, either PEMDA or DPRD respondents, by filling out the questionnaires using the google form application. The number of policymakers as a population (a higher-ranking public official) from PEMDA was 164 people, and the number of DPRD populations was 244. The number of returned questionnaires filled out by the higher-ranking public official was 31 percent, and DPRD was 34 percent.

The data from the questionnaires were analyzed using SPSS and presented descriptively. The respondents' answers to assess the extent to which the factors suspected of forming the policy formulation model were obtained from questionnaires and reinforced by the results of in-depth interviews by phone and researcher's observations while interacting with policymakers. As a reinforcement, data from online newspapers were juxtaposed with primary data to conclude the policy formulation process during the Covid-19 pandemic. 


\section{Results and Discussion}

\subsection{Problem Streams}

In early March 2020, after the central government determined Indonesia's status as a pandemic Covid-19, the regions followed government policies. However, some provinces want to choose their territory status beyond the government central's wants, i.e., locking down its territory in Jakarta. The center has prohibited that status and replaced it with the Large-Scale Social Restrictions (PSBB). DIY did not follow the central policy by either setting lockdown status or PSBB status. The interesting phenomenon is that many villages in DIY have unilaterally designated themselves as lockdown areas. This status created tensions because it disrupted the supply of goods and services in neighborhoods. Although some of these villages finally gave in after being pressured by local officials, several other villages still insisted on implementing the local lockdown status until October 2020.

The community's assertiveness to protect themselves by deciding their area's status to be locked down differs from the confusion at local government levels. They tend to wait for policies from the central government, even though Covid-19 sufferers' cases increased at that time. The primary data shows that more than 90 percent of respondents from PEMDA and DPRD answer that the spread of Covid-19 in DIY was worrying.

The data indicate that 72 percent of the PEMDA public officials are concerned that the increasing condition of the Covid-19 pandemic in Jakarta will impact the DIY. It is similar to respond 62 percent of DPRD members who also felt worried that the same thing would happen in DIY. Thus, the data on PEMDA and DPRD members' perceptions confirm that they face the same public problem, pandemic Covid-19. However, the conclusion of interviews with public officials made it clear that they were facing an unusual condition:

"We understand that this is a crisis that we cannot avoid."

(interview with Mr. A and Mr. B, informants from PEMDA).

PEMDA officials' understanding of the crisis is a determinant variable in shaping policies. They admitted that there must be quick actions to respond to the impact of the pandemic Covid-19. According to the DPRD members, there is an awareness to change the policy quickly (Table 1).

Table 1. The percentage of DPRD respondents who answer that the local government's response to the pandemic covid 19 was slow

\begin{tabular}{lc}
\hline $\begin{array}{c}\text { Government } \\
\text { Sector }\end{array}$ & $\begin{array}{c}\text { The response percentage of DPRD } \\
\text { respondents (\%) }\end{array}$ \\
\hline Health & 37 \\
Economic & 45 \\
Transportation & 39 \\
Social safety nets & 42 \\
\hline
\end{tabular}

Source: Primary data 
Many DPRD members responded that the local government's actions were slow. They considered that PEMDA's ability to manage sectors affected by Covid-19 were slow (i.e., 37 percent of the health sector, 45 percent of the economic sector, 39 percent of the transportation sector, and 42 percent of the social safety nets). The perception data from DPRD members showed that the PEMDA officials are not reasonably responsive to rapid policy problems, even though they have already been aware of the crisis. For example, informants C, D, E from DPRD criticized the health sector for not having valid data on how many people were infected and the available health facilities. Meanwhile, economic institutions have not been sufficiently alert in the economic sector to determine what economic sectors are affected by the pandemic and what local government policies should respond to pandemic impacts immediately. The DPRD complained about the unclear policy on vehicles allowed to enter and leave DIY in the transportation sector. In the social safety net sector, complaints related to the target group's data validity's unavailability and budget allocation.

Public officials often slow response to crises like pandemics because they have two choices to carry out their duties: changing work patterns into a pandemic crisis or maintain routine work. The data in the following Table 2 shows that PEMDA public officials are in doubt of responding to these two things.

Table 2. The percentage of public officials who answer activities carried out by government institutions when the pandemic spread

\begin{tabular}{lc}
\hline \multicolumn{1}{c}{ Type of activities } & $\begin{array}{c}\text { Percentage of answer } \\
(\%)\end{array}$ \\
\hline Discussing the formation of a task force & 86.57 \\
Refocusing the budget & 97.01 \\
Planning the scheme of remote working & 92.54 \\
Discussing strategies for dealing with the effects of covid & 97.01 \\
Implementing the institution's routine activities as usual & 31.34 \\
& \\
Discussing the local government work plans for 2021 & 91.04 \\
Making regular institutional reports & 94.03 \\
\hline
\end{tabular}

Source: primary data

When the pandemic began to break out, many public officials replied that they began discussing forming a task force for handling the Pandemic Covid-19 (87 percent). Some others also respond that they are refocusing the budget for managing the Pandemic Covid-19 (97 percent), planning Work from Home (WfH) for bureaucrats (93 percent), and discussing strategies for dealing with the effects of covid (97 percent). On the other hand, they also stated that they still had to discuss the local budget and program plan for 2021 (91 percent) and make regular institutional reports (94 percent). In Indonesia's bureaucratic system, both jobs are routine works of institutions that absorb more than 70 percent of working time. Therefore, some public officials answered (31 percent) that they still carried out regular 
activities.

The choice of public officials to focus on handling pandemics is something very positive in a crisis. However, the surprising answer was that as many as 13 percent of the officials said that they did not consider resolving public problems when asked what considerations their commitments were when determining the impact of Covid. Although 13 percent of them is still less than those who answered otherwise, it needs to find why they did not consider resolving public problems like the impact of Covid-19. Public officials who respond not to consider the pandemic are public officials from institutions who think that their institutional duties are not directly affected by the pandemic, for example, agriculture, information communication, settlements, youth and sports, and population. The GRDP data for 2020 shows that six sectors are still growing positively. These sectors are communication information (19.70 percent), health services (19.18 percent), education services (4.47 percent), agriculture (4.19 percent), real estate ( 1.27 percent), and water supply ( 0.51 percent)

The data above concludes that the pandemic has placed many public officials uncertain about what they should do, completing routine activities or responding immediately to a pandemic case. In other words, the pandemic was not the primary duty of public officials. Instead, the main task is still completing routine activities to comply with the budget 2020. Most public officials (79 percent) answer that another obstacle for making policies is budget constraints. They acknowledged that stringent regulations on using the budget prevented them from changing unilaterally without the central government's approval.

The next stage of the dispute was at the step of synchronizing program design with budget availability. Regarding this process, two secondary policymakers from the planning office and financial office played significant roles. The planning office would bring policy design to the financial office to determine the appropriate financial allocation. The finance office has greater power to intervene even alter planning office design in determining the budget. The following excerpt is a statement conclusion of two members of DPRD from a major political party:

"Finance office is the financial commander. It has a big role to change the policies that DPRD has formulated". (Informant C, H, DPRD).

The process of establishing a consensus between the planning office and the finance office is complex. The implementing institutions are often staggered by the decision from two institutions. Financial office considerations generally refer to the interpretation of the budget capacity, whereas planning office refers to the technical planning argument.

"The Finance office often steps out of their authoritative domain by using their argument concerning the interpretation of the budget effectiveness that may perhaps differ from the planning office interpretation upon the same issue" (Informant, F, PEMDA)

This fact concludes that the "money follow function" approach was not effective in policy formulation. The new government regulation that frees regional flexibility for budget refocusing to respond to a pandemic is still ineffective. It seems that local governments are still hesitant to implement this government regulation for fear of financial unaccountability. It 
also refocuses the budget requires a long discussion. Finally, the PEMDA and DPRD agreed to the budget changes in October 2020. In general, all budget components have decreased, as shown in Table 3 below:

Table 3. Local Budget Change DIY 2020

\begin{tabular}{clllr}
\hline \multicolumn{1}{c}{ Budget Items } & \multicolumn{1}{c}{ Old Target (IDR) } & \multicolumn{2}{c}{ New target (IDR) } \\
\hline Local Income & $\mathrm{Rp} 6130178110468.18$ & $\mathrm{Rp} 5469445329163.93$ \\
Local expenditure & $\mathrm{Rp} 6464711413219.80$ & $\mathrm{Rp} 5776925248459.35$ \\
Regional financing & $\mathrm{Rp}$ & 364533302751.62 & $\mathrm{Rp}$ & 307479919295.42 \\
a. Income & $\mathrm{Rp}$ & 543163302751.62 & $\mathrm{Rp}$ & 425069919295.42 \\
b. Expenditure & $\mathrm{Rp}$ & 178630000000.00 & $\mathrm{Rp}$ & 117590000000.00 \\
\hline
\end{tabular}

Source: (Dprd-diy.go.id, 2019)

The confusion among public officials increased when the governor of DIY do not want to implement the lockdown but "calm down" and "slow down" instead. The meaning of "calm down" is not panic but awareness of the dangers of a pandemic, while "slow down" is defined as an activity not to harm others through disease transmission. Even though the meaning of calm down and slow down is perfect, it is an indirect signal from the governor to public officials not to change policies that can frighten the public (Gatra.com, 2020). The governor, as the king, never left the principles of Javanese culture in making policies "wong sabar rejekine jembar, ngalah urip luwih berkah." It means that humans must be patient with this problem and let it run as it is. This principle dominates the thinking of public officials to make policy in this region. The policies made do not recognize drastic changes because public officials must calculate according to the previous conditions' achievements (incremental approach). The conclusion is that the definition of policy problems with various indicators generally ends up in a definition of policy problem by the Governor's orders. All parties in the executive and legislative branches must follow the definition of the problem decided by the governor.

\subsection{Policy Streams}

The local government used data from the central government (98.51 percent) for policymaking. Most public officials were panic because there were no valid data to prevent the impact of pandemic Covid-19. It was also exciting data when PEMDA took data from information developed in newspapers (71.64 percent) and social media (58.21 percent) as well intuition (56.72 percent) (see Table 4).

Table 4. Sources of information for policymaking according to the public official's answer

\begin{tabular}{lcc}
\hline Sources of Information for Policy Making & $\begin{array}{c}\text { Yes } \\
\%\end{array}$ & $\begin{array}{c}\text { No } \\
\%\end{array}$ \\
\hline Central government policy & 98.51 & 1.49 \\
Official research institute & 95.52 & 4.48 \\
Academic Institution & 92.54 & 7.46 \\
Social media & 58.21 & 41.79 \\
Newspaper & 71.64 & 28.36 \\
Intuition & 56.72 & 43.28
\end{tabular}


Superiors statement

Political parties

Community organization

Citizens

Sources: Primary data

The absence of valid information about covid has created a wrong policy response to prevent it. Examples of such destructive policies are that the central government requires that public facilities spray disinfectants on humans directly, pay more attention to the economy than the health sector, the ineligible target group of social safety nets and the choice to implement PSBB. This last policy, President Jokowi admitted that the PSBB policy was ineffective and replaced it with a Restriction on Community Activities (PPKM) policy in January 2021.

The central and local governments had become powerless in facing the confusion of knowledge regarding effective pandemic handling. The policy response made by the DIY government is similar to the garbage can from Cohen et al. (2014). Any information from anyone could be a piece of accurate policy information without filtering the information source's accuracy.

The impact of uncertainty in government policies made public trust in the government lowest in 2020. Response for impatience of the DIY community was such as continuing local lockdowns in their villages. Exit voices from experts and the public used newspapers and social media to implement a total lockdown in DIY. However, the provincial and districts government tend to wait for policies from the central government. It is in line with nearly 100 percent of the PEMDA and DPRD answered using central government regulations as the primary source for policymaking.

The central government issued the Government Regulations Substitute to Law (2020) in April 2020 (Perppu), which frees each region to refocus its budget for overcoming a pandemic outbreak. Furthermore, it makes it easier for PEMDA to technically adjust its budget to manage better the pandemic impact, especially the health, economy, social safety nets, and transportation sectors. In addition, this Perppu makes local governments more confident when responding to critics in managing the impact of the pandemic.

The central policy decided that the policy choices are more likely to strengthen the economy rather than health to prevent a pandemic. As a result, the central government's presence in regions policymaking to handle the pandemic has grown stronger since August 2020. Since then, DIY has always followed the central decision as a basis for policymaking.

The local government's role in handling the pandemic Covid-19 has led to the re-appearance of the classic conflict between the technocratic approach (planning office) and financial administration (financial office). The governor will let the different points of view between them avoid hegemony in interpreting his vision. He understands that his subordinates often feel hesitant with his presence in meetings. To overcome this obstacle, the governor established them as secondary policymakers to use their authority. Thus, their conflict can remain to be managed by the governor. The planning office and financial office each have policy communities to formulate policy. The planning office as a technocratic agency works 
based on data analysis of public affairs, while the financial office work with financial capacity and rules. Both sides are a large coalition in the process of policy formulation in DIY administration. This phenomenon is a negotiation between two sections with different views and interests to find common ground in formulating policies.

This policy stream coincides with the problem streams, between the importance of utilizing empirical data in policy formulation and the strength of policies determined by the center in finance. The governor's role in opening this deadlock is essential. His ability to unite central and regional interests through approaches to the central government and unify different regions' interests has resulted in the right policies. He used the pandemic crisis as a policy window to reconcile differences and produce effective policies.

\subsection{Political Stream}

DIY is a special province in Indonesia. The governor of DIY represents the central government and also the king of the Kingdom in DIY. The relationship between the Sultan and the center during the Jokowi era was relatively conducive to the previous central administration period. Therefore, the Sultan's political position as governor is relatively strong. However, the Sultan experienced legitimacy due to internal conflict regarding the next successor to the throne. The inner political turmoil within the kingdom had heated the political situation between various groups, which also influenced how the Sultan's legitimacy was in front of the people and the political forces in Yogyakarta.

This pandemic's emergence revived the Sultan's political position towards the central government and his people in the regions. The central government's legitimacy decreased by the extreme political differences between political groups as a direct impact of the presidential election in 2019. It tended to weaken the legitimacy of the central government. DIY needs a solid leader to handle the impact of the pandemic. Sultan Hamengkubuwono X represented this need. As a king, he has established himself as a policy entrepreneur. Therefore, this pandemic has prompted the Sultan to re-strengthen his political position in DIY.

As previously explained, the program's design for controlling pandemics has some interests, particularly between the planning and implementing institutions. The planning office still insisted on their interpretation of the governor's vision to reduce pandemic impacts. On the other hand, the implementing institution generally believes that the program is routine work in the previous fiscal years. This difference of interests also occurs in a pandemic situation, rendering the policy draft dispatched back and forth between the planning office and the implementing institution responsible for its technical implementation. An example is an implementing agency that considers keeping the expenditure on goods in the 2020 budget. On the other hand, the planning office believes that these goods' logistics expenditures should be replaced and allocated to logistics expenditures on goods needed to respond to a pandemic's impact, such as medical equipment.

Nevertheless, this process remains true to the proper courses of the technocratic approach. Lobbying in this stage happened between the planning office and the implementing institution through informal dialogue between the institutional heads. Data from the 
questionnaire confirm that 81 percent of the public officials said that they would compromise when there were differences in data among institutions. The remaining (13 percent) left it to the institutional decision of the respective government institution, and 6 percent of them went it to the institution's head.

In the Indonesian bureaucratic culture, every formulating program must consider equity for units and positions in the organization. If bureaucrats ignored it, the program implementation would disrupt. However, actors can resolve the difference in interest in designing the program because all parties felt they had acquired a part of that fiscal year's plan. Most public officials (99 percent) responsible for handling this pandemic admit that they can control conflicts of interest between them. They always refer to central government policies and policies decided by the governor.

Pemda and DPRD will discuss the local budget plan's policy design and the DPRD to ratify the typical situation's arrangement. It is included in the policy design phase because the legislation process may change the initial setup. In addition, DPRD had only begun involving during the local budget plan for the program's distribution under its interests.

"DPRD often requests changes in the amount and location of target groups. They intentionally increased the number of targets and locations of residents in the case of social safety nets before they ratify the program design". (Informant G, PEMDA)

The process of social safety nets frequently experienced political pressures during the implementation. For example, changes in the number of recipients during the plan and the implementation stage of social safety nets happened because DPRD members must comply with their promises to their constituents.

The political process of program budgeting during a pandemic is different from the process in typical situations described above. The executive is sticking to Perppu No.1/2020, particularly Article 3 (1), which gives regional governments the flexibility to prioritize the use of budget allocations for specific activities (refocusing), change allocations, and use of local budget (APBD), especially in the context of handling a pandemic. Article 27 (2) emphasized that there is protection for public officials included in the Financial System Stability Committee (KSSK) not to be criminalized or convicted in carrying out handling the impact of the Covid 19 pandemic. Even paragraph 3 emphasized that all actions, including decisions taken following this Perppu, are not the object of a lawsuit that can be sent to the State Administrative Court.

One main point in the political stream is still a governor ordered. Technocrats gathered in the Budget Team (TAPD) attempts to translate it into programs design. The formulation process tends to be concise, involving a few actors, one-way, and top-down centric. The successful program design lies in harmonizing programs as an interpretative form of the order in the bureaucracy. Public officials conveyed this order as a policy in figurative and symbolic expressions. The planning office stated that the governor ordered the implementation office to translate his wishes.

"The governor bypasses the agenda-setting stage by deciding which topics are a priority. Then he instructed the planning office by giving orders symbolically. For example, the governor's wish regarding development is "I want pandemic corona in 
here to decline" and "when will I be cutting the ribbon." (Informant A, PEMDA)

These symbolic expressions cannot be directly made into program design as the literal translation means. In the governor's words of "I want pandemic in here to decline," this compels the planning office to design policies and break down programs that are relevant in attaining the mandate of reducing pandemic. Simultaneously, the expression "when will I be cutting the ribbon," stated by the governor, is a symbolic speech in which he wishes to carry out a program with far-reaching impacts and implications. Then it requires the officials to translate the governor's intent into a policy design and plan for controlling the pandemic.

\subsection{Policy Window and Governor as a Policy Entrepreneur}

This pandemic era is the governor's policy window to restore his subordinates' trust in the PEMDA and DPRD. Even at the same time, this is an excellent opportunity to gain legitimacy in the regional community's presence, whose issues of succession to the throne have eroded. The governor understands during the COVID-19 pandemic, DIY needs a solid leader to unify various confusion of data, unclear policies from the center, and political frictions at the national level that are very sharp and influential in regions including DIY.

The problems, policies, and politics stream united into policies during the pandemic seemed like they did not have a solid policy basis. Policymakers in DIY panicked when they faced the absence of valid data and unclear policy from the central. They face a situation where the community is getting impatient with what the government is doing. Many villages make their policies to secure their respective territories by locking down their villages. The governor saw public opinion and led to low public acceptance of the quality of central government policies as an opportunity to reunite all components of the DIY community. The approaches taken by the province seem to be cautious because they do not want to conflict with central government policy. However, this was where the Sultan's ability was able to reduce pressure from the DIY community. On the other hand, he did not want to conflict with the central government, which faced extreme public pressure to make a national lockdown option.

By taking advantage of his cultural position, the governor was able to get different parties back together to protect the DIY community from the worse impact of Covid-19. Even DIY was able to produce innovative breakthroughs to suppress the spread of Covid-19 at least until October 2020. He showed the ability to involve all communities in the prevention activities of a pandemic. It is a kind of policy innovation in a community-centered approach. This innovation made Jogja in August 2020 receive an award from the center as the best province in coping with Pandemic Covid-19.

The governor is the main point of reference in formulating the strategic issues to be executed into the bureaucracy's policy designs. In addition, the governor gives macro-oriented instructions that the relevant institutions will subsequently translate. The former policy inputs come from participants in periodic coordinative meetings held by the local government. This process is similar to the situation in which the governor considers his advisors' suggestions. The latter comes from the governor's relations with internal bureaucrats, particularly officials from strategic institutions such as the financial office, planning office, and DPRD. In the end, to ensure the government's vision from being hegemonized by personnel at the lower level, 
the governor will unite two big offices, the planning office, and the financial office, concurrently by one public official in 2020. This position's concurrency maintains mutual oversight in formulating policies that are in accord with his conceptions. Hence, the governor's orders are a foundation of the province's agenda-setting that determines the priority of issues transmitted into the bureaucratic machinery.

These orders have a positive aspect as it simplifies the long agenda-setting process. However, it has a negative impression due to the loss of a more extensive public participation process. The governor's instructions are duly translated into a policy design by the subordinating bureaucratic machinery. This rigid process is related to the governor's status as a king, which bears implications over his administrative and political authorities (Mallarangeng \& Tuijl, 2004). This condition eliminates models, such as problem diagnosis (Weimer \& Aidan, 2011) and problem verification (Patton et al., 2015), when systematically setting priority issues. There is no stage of filtering issues through various methods conducted by the bureaucrats. As Dunn (2018) stated, agenda-setting is the stage in which strategic issues are formulated based on levels of urgency by key actors. The wisdom of the governor circumvents the style of the technocratic system.

The governor is present as a single policy entrepreneur who determines the motives underlying the government's policy formulation. There are no other policy entrepreneurs except for the Sultan who can unify the problem stream, policy stream, and political stream. The Sultan can harmonize these three aspects since he can intervene in those aspects via macro-oriented instructions. Therefore, it may refer to the governor's dominance in determining strategic issues during the agenda-setting process.

The governor, apart from being a policymaker, is also a policy entrepreneur. All interviewed informants from both the PEMDA and the DPRD approved the governor's opinion as a policy entrepreneur. Hence, this finding proves a difference in the entrepreneur policy concept described by John W. Kingdon. If Kingdon believes that the policy entrepreneur is the closest person to the policymaker, then a policy entrepreneur in DIY's policymaking is the governor as a policymaker. The argument is that the governor, as a king, has a great power to intervene in all policy problems and unite all groups in this region.

\section{Conclusion}

This research found that the administration system that combines monarchy and decentralization has encouraged crises to be resolved more quickly through integrated multiple streams. This study also found that the Covid-19 Pandemic was not just a public problem. Still, policymakers could use it as a policy window to unite various streams from a problem, policy, and political side.

In the problem streams, noise occurs when there is no valid data with precise crisis indicators. The financial crisis limited the government to overcome all the effects of the pandemic crisis. Besides, the center's policy streams also do not provide certainty about the policy choices. There is not enough information, knowledge, and technology to solve the crisis. Hence, the public is confused with unclear policies that have a political and managerial impact on the 
government. Political streams from the center disrupted the regions because political friction was still occurring at the national level. Meanwhile, the areas experienced political conflict due to past policies that ignored the local community's socio-cultural factors.

In this crisis, the governor, with his social insight, can bridge the different definitions of pandemic problems among actors. He could unify the regions' policy streams with the central policies without conflicting with the center's interests. It resulted in his political position at the center being even more vital. Solid political support from the center has become a valuable asset for him in uniting the various attitudes of groups in the regions at the bureaucratic, political, and community levels to support his idea of solving the pandemic's impact. Thus, the governor builds a network that spreads on all fronts, including making concurrent positions as public officials who hold the most vital functions in his government.

Another new finding is that the governor has a dual role as a policymaker and a policy entrepreneur. His role as a policy entrepreneur could arise because of his position as a king in this region. This finding is slightly different from the model proposed by John W. Kingdon regarding the policy entrepreneur as an individual, group, or organization close to the policymaker. Instead, this study finds evidence that the policy entrepreneur is in the same position as the policymaker.

\section{Acknowledgments}

The author is grateful for the data provided by the Graduate School of Leadership and Policy Innovation, Universitas Gadjah Mada (UGM).

\section{References}

Basheka, B. C., \& Byamugisha, A. (2015). The state of Monitoring and Evaluation (M\&E) as a discipline in Africa From infancy to adulthood? African Journal of Public Affairs, 8(3).

Blomkamp, E., Sholikin, M. N., Nursyamsi, F., Lewis, J. M., \& Toumbourou, T. (2017). Understanding Policymaking In Indonesia: In Search Of A Policy Cycle. In pshk.or.id.

Brzezinski, Z., Mahbubani, K., \& Xuetong, Y. (2013). The Post-Hegemonic Age. New Perspectives Quarterly, 30(2), 16-19.

Cairney, P., \& Jones, M. D. (2016). Kingdon's Multiple Streams Approach: What Is the Empirical Impact of this Universal Theory? Policy Studies Journal, 44(1), 37-58. https://doi.org/10.1111/psj.12111

Cohen, G., Schroeder, J., Newson, R., King, L., Rychetnik, L., Milat, A. J., Bauman, A. E., Redman, S., \& Chapman, S. (2014). Does health intervention research have real world policy and practice impacts: Testing a new impact assessment tool. Health Research Policy and Systems, 13(1), 1-12. https://doi.org/10.1186/1478-4505-13-3

Cohen, M. D., March, J. G., \& Olsen, J. P. (1972). A Garbage Can Model of Organizational Choice. Administrative Science Quarterly, 17(1), 1. https://doi.org/10.2307/2392088

Colebatch, H. K. (2006). What work makes policy? Policy Sciences, 39(4), 309-321. 
https://doi.org/10.1007/s11077-006-9025-4

Dprd-diy.go.id. (2019). Audiensi dari Komite Olahraga dan Rekreasi Masyarakat Indonesia.

Dunn, W. (2018). Public Policy Analysis: An Integrated Approach. Routledge.

Easton, D. (1965). A System Analysis of Political Life.

Eising, R. (2013). WAI-ZEI Paper No. 7: Theories of Policy Formulation. https://www.researchgate.net/publication/280699168_WAI-ZEI_Paper_No7_Theories_of_Pol icy_Formulation?enrichId=rgreq-69ed029562ffadfb355ccb712dcf8752-XXX\&enrichSource= Y292ZXJQYWdlOzI4MDY5OTE2ODtBUzoyNTg5OTYxMDM4MDY5NzZAMTQzODc2 MDg5MTEyNg\%3D\%3D\&el=1_x_3\&_esc=publicationCoverPdf

Feldman, D. C. (1989). Careers in Organizations: Recent Trends and Future Directions. Journal of Management, 15(2), 135-156.

Gatra.com. (2020). Raja Yogya: Rakyat Jangan Ditakuti Corona, Kelaparan Nanti. Https://Www.Gatra.Com/Detail/News/490787/Kesehatan/Raja-Yogya-Rakyat-Jangan-Ditakut i-Corona-Kelaparan-Nanti.

https://www.gatra.com/detail/news/490787/kesehatan/raja-yogya-rakyat-jangan-ditakuti-coro na-kelaparan-nanti

Government Regulations Subtitute to Law. (2020). Kebijakan Keuangan Negara dan Stabilitas Sistem Keuangan Untuk Penanganan Pandemi Corona Virus Disease 2019 (COVID-19) Dan/Atau Dalam Rangka Menghadapi Ancaman Yang Membahayakan Perekonomian Nasional Dan/Atau Stabilitas Sistem Keuangan.

Indonesian Constitution Law Number 13. (2012). Undang-Undang Republik Indonesia Nomor 13 Tahun 2012 Tentang Keistimewaan Daerah Istimewa Yogyakarta. In Republik Indonesia.

jogjaprov.go.id. (n.d.). hamemayu hayuningbawono. Https://Jogjaprov.Go.Id.

Kingdon, J., \& Stano, E. (1984). Agendas, alternatives, and public policies. Litle, Brown.

Kingdon, J. W., \& Brodkin, E. (2014). Agendas, Alternatives, and Public Policy. In Political Science Quarterly (Vol. 100, Issue 1). https://doi.org/10.2307/2150882

Kingdon, W. J., \& Stano, E. (1984). Epilogue: Agendas, Alternatives and Public Policies.

Kurniadi, B. D. (2009). Yogyakarta in Decentralized Indonesia: Integrating Traditional Institution in Democratic Transitions. Jurnal Ilmu Sosial Dan Ilmu Politik, 13(2), 190-203. https://doi.org/10.22146/JSP.10961

Mallarangeng, A., \& Tuijl, P. Van. (2004). Partnership for governance reform in Indonesia: Breaking new grounds or dressing-up in the Emperor's new clothes?: A response to a critical review. Third World Quarterly, 25(5), 919-942. https://doi.org/10.1080/0143659042000232027

Meijerink, S., \& Huitema, D. (2010). Policy entrepreneurs and change strategies: Lessons 
from sixteen case studies of water transitions around the globe. Ecology and Society, 15(2), 17. https://doi.org/10.5751/ES-03509-150221

Mintrom, M. (2011). Contemporary policy analysis (Issue July). Oxford University Press. https://doi.org/https://www.researchgate.net/publication/341287616_Contemporary_Policy_A nalysis

Mintrom, M., \& Norman, P. (2009). Policy Entrepreneurship and Policy Change. Policy Studies Journal, 37(4), 649-667. https://doi.org/10.1111/j.1541-0072.2009.00329.x

Mitroff, I., \& Blankenship, L. V. (1973). On the Methodology of the Holistic Experiment: An Approach to the Conceptualization of Large-Scale Social Experiments. Technological Forecasting and Social Change, 4, 339-353.

Novotny, T. E., Bialous, S. A., Burt, L., Curtis, C., da Costa, V. L., Iqtidar, S. U., Liu, Y., Pujari, S., \& D'Espaignet, E. T. (2015). The environmental and health impacts of tobacco agriculture, cigarette manufacture and consumption. Bulletin of the World Health Organization, 93(12), 877-880. https://doi.org/10.2471/BLT.15.152744

Patton, C. V., Sawicki, D. S., \& Clark, J. J. (2015). Basic methods of policy analysis and planning. In Basic Methods of Policy Analysis and Planning. https://doi.org/10.4324/9781315664736

Pellini, A., Prasetiamartati, B., Nugroho, K. P., Jackson, E., \& Carden, F. (2018). Knowledge, politics and policymaking in Indonesia. In Knowledge, Politics and Policymaking in Indonesia. Springer Singapore. https://doi.org/10.1007/978-981-13-0167-4

Sabatier, P. (2007). Theories of the Policy Process. In Westview Press. https://doi.org/10.4337/9781784714871.00013

Simon, H. A. (1955). A Behavioral Model of Rational Choice. The Quarterly Journal of Economics, 69(1), 99-118.

Tribunjogja.com. (2020). Pemulihan Ekonomi DI Yogyakarta dengan Refocusing Anggaran. Https://Jogja.Tribunnews.Com/2020/10/24/Pemulihan-Ekonomi-Di-Yogyakarta-Dengan-Ref ocusing-Anggaran.

https://jogja.tribunnews.com/2020/10/24/pemulihan-ekonomi-di-yogyakarta-dengan-refocusi ng-anggaran

Weimer, D. L., \& Aidan, V. R. (2011). Policy Analysis Concepts and Practice.

Zahariadis, N. (2008). Ambiguity and choice in European public policy. Journal of European Public Policy, 15(4), 514-530. https://doi.org/10.1080/13501760801996717

Zohlnhöfer, R. (2016). Putting Together the Pieces of the Puzzle: Explaining German Labor Market Reforms with a Modified Multiple-Streams Approach. Policy Studies Journal, 44(1), 83-107. https://doi.org/10.1111/psj.12135 


\section{Copyright Disclaimer}

Copyright for this article is retained by the author(s), with first publication rights granted to the journal.

This is an open-access article distributed under the terms and conditions of the Creative Commons Attribution license (http://creativecommons.org/licenses/by/4.0/). 